\title{
The Formation of Krasnoyarsk State Institute of the Arts
}

\author{
Galina Baranova \\ Krasnoyarsk State Institute of the Arts \\ Music Faculty \\ Kransoyarsk, Russia \\ E-mail: sosedkina_3@mail.ru
}

\author{
Irina Efimova \\ Krasnoyarsk State Institute of the Arts \\ Music Faculty \\ Kransoyarsk, Russia \\ E-mail: acamus.cabinet@mail.ru
}

\begin{abstract}
The case study presented in the article has strong correlation to "Musical local studies" course that is included into state educational standard for higher education. The history of Krasnoyarsk State Institute of the Arts saved in archive documents has been for the first time revealed to the reader who can trace back the foundation of the Institute and estimate the creative capacity that made it one of the most notable centres of art education and art culture in Eastern Siberia. The article presents local documentary evidence on the opening of the first Art Institute in Krasnoyarsk. As the title implies, the article describes the development of the Institute in the first five years of its operation. Special attention is paid to the structure and activity of the Institute and to the formation of its creative team.
\end{abstract}

Keywords-musical local history; Krasnoyarsk State Institute of the Arts; archival fund of Krasnoyarsk State Institute of the Arts foundation; structure; higher education

\section{INTRODUCTION}

The foundation of an Art institute right in the centre of Siberia was naturally determined by the cultural boom that was overwhelming Krasnoyarsk Krai and especially its capital in the late 70s of the XX century.

The cultural breakthrough was characterized by the opening of Opera and ballet theatre, foundation of local philharmonic orchestra and the state Institute of the Arts on February 19. Such a flare of creative enthusiasm could not be noticed anywhere else in the country at that time.

The decision of the Ministry of Culture to found the State Institute of the Arts in Krasnoyarsk was made after the issue of a resolution signed by M.S.Solomentsev - Chairman on Council of Ministers and executive officer I. Smirnov dated October 19, 1977, No 529. For that matter Krasnoyarsk communist party bureau and Krasnoyarsk Krai regional executive committee resolved on December 3, 1977: "to oblige all party committees, authorities and departments of Krasnoyarsk and Krasnoyarsk Krai to place the greatest emphasis on founding the State Institute of the Arts, hiring the staff and making necessary preparations for the institute to be opened by September 1, 1978 and handling all the matters concerning this case" ${ }^{1}$. Special instructions were given on finding appropriate premises for the studies and accommodation for students and professors, providing the institute with necessary instruments and materials etc. As a result, at the beginning of the studies the Institute occupied three buildings (one of them on lease).

The resolution also contained a lay-out of the Institute structure: there had to be three faculties: Music Faculty with the departments of piano, orchestra instruments, folk instruments, vocal department, choral conducting, composing, music studies; Drama Faculty with the departments of theatre and cinema acting, drama studies, puppets theatre acting; Fine Arts Faculty with departments of painting, interior and equipment, monumental and decorative art.

\section{ORGANIZING THE WORK}

The first Rector of the Institute, Professor Gerald Aleksandrovich Belousov, had a degree in Law and ruled the institute till 1989. He managed to form the core staff, approve the curriculum, organize research and pastoral work and founded social science council.

The managing board responsible for the Institute's opening included: K.M.Chernov (regional party council secretary, Head of the board), M.I. Zharkov ( Deputy Chairman of executive committee of regional party council, Deputy Head of the board), B.V. Guskov (head of culture department at regional party council), A.I. Morev (head of executive committee of Krasnoyarsk city council), I.M. Naumov (deputy director of Glavkrasnoyarskstroy), B.A. Palchikov (Head of regional culture authorities) etc.

One of the most urgent matters was to find and equip classes for study and workshops as well as to form the staff and enroll students. The evidence of that can be found in resolution of Krasnoyarsk party committee and executive committee of regional party council dated December 3, 1977, No 97: " to oblige the culture department (Guskov), science and educational institutions authorities of regional party council (Semenov), regional culture authorities

\footnotetext{
${ }^{1}$ Archive of Krasnoyarsk State Institute of the Arts, file:" Documents on foundation of Krasnoyarsk State Institute of the Arts"
} 
(Palchikov) to render possible assistance in gathering the team of teachers and professor, before August 1, 1978...... Soviet, party, trade unions and Komsomol organizations to suggest future students that can be enrolled out of the best graduates of art schools and colleges, to propose enrolling some gifted amateur club directors" $"$.

The foundation of the Institute of the Arts, according to the articles published in local press in 1978 [6, p.2], became one of the most significant events in Krasnoyarsk Krai history. One of the journalists expressed his feelings with the following words: "... apparently, the educational process will be far from standards, instead one can find the whole world of unperceivable waiting for being discovered. There will be everlasting work, emotional education, learning and mastering ... transfer of traditions fully formed in the art." [4, p.2].

\section{STUDIES AND EDUCATIONAL WORK}

As it was stated above, at the beginning three Faculties were opened for full-time and part-time studies. In 197819808 Chairs functioned: Chair of Marxism-Leninism and general science, Chair of additional and major piano, Chair of orchestra instruments, Chair of solo and opera singing, Chair of choral conducting and music theory, Chair of acting, Chair of applied and decorative arts. All the Chairs that exist at present evolved in the first 5 years of the Institute functioning.

During the first academic year 52 lecturers and teachers worked at the Institute, including 24 working full-time and 28 employees were paid hourly wage. Among them were 2 acting professors, 3 associate professor, 1 acting associate professor, 5 senior teachers and other teachers and assistants. Along with the increasing of total number of students more lecturers were added and the staff gradually widened to 87 people in 1979-1980 academic year, 124 in 1980-1981, 143 in 1981-1982 and 155 in 1982-1983. The number of students rose correspondingly: 118 students in the first academic year, then, by 1982 the number increased 5 times to 563 including 371 students at Musical Faculty, 95 studied drama and 97 fine and applied art.

Sustained effort had been made in the first academic year to organize the process of study. A project of Charter was made up and transferred to the admission committee of the Ministry of Culture of RSFSR in autumn of 1978; academic calendar and academic planning schedule, educational outreach plan, study audit instruction, students' group mentors regulation and other documents providing stable work of any educational institution were finalized and admitted. The Chair of drama acting gave opportunities to its students to do internship at the regional drama theatre named after A.S. Pushkin ${ }^{3}$.

The Institute faced some obstacles in the first year of work, such as slight shortage of experienced staff, and

\footnotetext{
${ }^{2}$ The same source

${ }^{3}$ Students were signed up to the following courses: acting, scenic speech, dance, stage movement, rhythm studies, history of world theatre, history of world literature
}

therefore had to hire teachers from Krasnoyarsk Arts College and other leading teachers of Krasnoyarsk including Natan Israilevich Basin (Chief conductor of the regional drama theatre named after A.S. Pushkin, Honored Artist of RSFSR), Nariman Evgenievich Chunikhin (Chief conductor of Musical comedy theatre, Honored Artist of RSFSR), Boris Yakovlevich Ryauzov (corresponding member of the Soviet Academy of Arts, People's artist of RSFSR), Yuri Pavlovich Ishkhanov (People's artist of RSFSR), Ivan Vsevolodovich Shpiller (Chief conductor of Krasnoyarsk symphony orchestra), Maksimilian Stanislavovich Vysotsky - Chief director and Igor Leonidovich Shavruk - Chief conductor at Opera and ballet theatre etc. Those experienced and talented artists along with Heads of Chairs and other departments of the Institute formed the first Academic board that directed the work of the staff right from the start of the first academic year.

However, not only the "elders" were engaged in the process of institute formation, but lots of young talents directed their energy and passion to the common goal of the staff. Basically they were graduates from the largest arts institutes of the country: Moscow State Institute of Music and Teaching named after the Gnesins, Conservatories of Leningrad, Ural, Novosibirsk and other higher educational institutions. The highest standards and deeply-rooted traditions of those music schools became the basis of the new system of higher education making up in the centre of Eastern Siberia.

Studies, tutorials, performing - all kinds of work inside the Institute as well as the process of cultural society formation were held under the "Make Siberia a region of high-level culture" slogan. It goes without saying that the teachers and professors were not restricted and acted beyond the limits of that message and worked applying classical methods of Russian art education system. One of the principles of such methods is inseparable unity of teaching techniques, education, research, performing and creative work (turn to [5] for the details).

\section{CONCLUSION}

The Institute had achieved outstanding results by the end of the first 5-year period of its life owing to high level of professional skills and commitment of its staff. It can be proved by the students' high grade average: $94.4 \%$ passed the exams in the first year -then $94.5 \%-95.5 \%-92.7 \%$ 91.9\%. Exam pass rate for Chair of additional and major piano, Chair of orchestra instruments, Chair of solo and opera singing, Chair of choral conducting and music theory) reached $100 \%$. Thus, the Institute proved from the very beginning to have excellent art potential of its workers and students.

Having made remarkable contribution to the state programme of forming cultural society under the moto "Make Siberia a region of high-level culture" the young art school met the expectations of the Ministry of Culture. Now we can claim that the Institute carried on the long-lasting Traditions of higher musical education of our Homeland. 


\section{REFERENCES}

[1] Historical Encyclopedia of Siberia. Vol. 2. Novosibirsk: Publishing house "Siberia Historical Heritage". 2009. 805 p.

[2] Krasnoyarsk State Academy of Music and Theatre. 25 years. Krasnoyarsk: Publishing house "Krasnoyarsk State Academy of Music and Theatre". 2003. 238 p.

[3] Krasnoyarsk State Academy of Music and Theatre: encyclopedic reference. Krasnoyarsk: Publishing house "Krasnoyarsk State Academy of Music and Theatre". 2010. 184 p.

[4] Kustov. V. Moments of joy. Krasnoyarsk Komsomolets. 1978. № 106 (5690). P. 2.

[5] Sosedkina G.V. Music education in pre-revolutionary and Soviet Russia: the problem of succession: Final qualifying work. Krasnoyarsk: Based on the manuscript. 2014. 91 p.

[6] Vinskaya L. The first step to dream. Krasnoyarsk worker. 1978. № 208 (17899). P. 4. 